\title{
The Influence of Porous Features on the Electrochemical Performance of Its Supported Platinum Catalyst in Porous Carbon Nanofibers
}

\author{
Fangyi Mao, Yang Wang, Kang Fu, Junhong Jin, Shenglin Yang, Guang Li* \\ State Key Laboratory for Modification of Chemical Fibers and Polymer Materials, College of Materials Science and Engineering, \\ Donghua University, Shanghai, China \\ Email: *lig@dhu.edu.cn
}

How to cite this paper: Mao, F.Y., Wang, Y., Fu, K., Jin, J.H., Yang, S.L. and Li, G. (2017) The Influence of Porous Features on the Electrochemical Performance of Its Supported Platinum Catalyst in Porous Carbon Nanofibers. Journal of Materials Science and Chemical Engineering, 5, 10-18. https://doi.org/10.4236/msce.2017.57002

Received: April 12, 2017

Accepted: July 4, 2017

Published: July 7, 2017

\begin{abstract}
Porous carbon nanofibers (PCNFs) were prepared through electrospinning, pre-oxidation and carbonization with polyacrylonitrile (PAN) as carbon precursor and polymethyl methacrylate (PMMA), $\mathrm{CaCO}_{3}$ as pore-forming agents. The structure, morphology, specific surface area and electrochemical performance of the carbon nanofibers were characterized by scanning electron microscopy (SEM), transmission electron microscopy (TEM), $\mathrm{N}_{2}$ adsorption/desorption method and electrochemical tests. Compared with PCNFs without $\mathrm{CaCO}_{3}, \mathrm{PCNFs}\left(\mathrm{CaCO}_{3} 1 \%\right)$ had higher specific surface area, better dispersion of Pt nanoparticles, and the particle size become smaller, which was corresponding with the results of electrochemical performance test. It could be seen in cyclic voltammetry (CV) and linear sweep voltammetry (LSV) test, ECSA of $\mathrm{Pt} / \mathrm{PCNFs}\left(\mathrm{CaCO}_{3} 1 \%\right)$ attained $82 \mathrm{~m}^{2} \cdot \mathrm{g}^{-1}$, while that of JM20 and Pt/PCNFs without $\mathrm{CaCO}_{3}$ were $77 \mathrm{~m}^{2} \cdot \mathrm{g}^{-1}$ and $60 \mathrm{~m}^{2} \cdot \mathrm{g}^{-1}$, respectively. These results revealed that $\mathrm{CaCO}_{3}$ as the second pore-forming agent can further increase the mesoporous number and specific surface area of nanofibers, and can improve the electrochemical properties of Pt catalyst as the support.
\end{abstract}

\section{Keywords}

Porous Carbon Nanofibers, $\mathrm{CaCO}_{3}$, Electrospinning, Catalyst Support, Oxygen Reduction Reaction

\section{Introduction}

Nowadays with the shortage of energy resource and serious pollution of our environment, fuel cells with their advantage of being a clean and efficient energy 
have been the focus of the recent studies. The electrocatalyst plays a decisive role in the performance of fuel cells. At present, platinum catalyst is mainly used in the fuel cell, which has great catalytic activity, chemical stability, and exchange current density [1].

Carbon support is one of the key components of the catalyst, which not only directly affects the particle size, dispersion and activity of the catalyst, but also affects the conductivity, mass transfer and specific surface area of the catalyst. [2] For carbon support, the size and distribution of the pores on it affects the dispersion and size of Pt nanoparticles, which in turn affects the performance of the catalyst. Commonly used support materials are mesoporous carbon, carbon nanotubes, porous carbon nanofibers and graphene [3]-[9]. There has been research focus on PCNFs as support. Álvarez et al. [10] found that Pt/CNFs catalysts show a better performance when compared to Pt/Vulcan XC-72R catalyst in the same fuel cell environment, may result from the smaller number of micropores in carbon nanofibers increasing the use of the Pt catalyst. This indicated the possibility of improving the electrochemical performance of the catalyst by improving the feature of the pores in the carbon nanofibers as support.

The previous work [11] showed that PCNFs were successfully prepared from polyacrylonitrile/polymethyl methacrylate (PAN/PMMA) blend solution by electrospinning, preoxidation and carbonization steps, and got better electrocatalytic performance on its supported platinum catalyst than Commercial electrocatalyst. In order to further improve the specific surface area and increase the abundance of the pores on PCNFs, this paper introduced $\mathrm{CaCO}_{3}$ as the second pore-forming agent into the PAN/PMMA system, and more pores were formed by $\mathrm{CO}_{2}$ derived from thermal decomposition of $\mathrm{CaCO}_{3}$.

\section{Experimental}

\subsection{Materials}

Dimethylacetamide (DMAc), ethylene glycol (EG), Methanol and hexachloroplatinic acid $\left(\mathrm{H}_{2} \mathrm{PtCl}_{6} \cdot 6 \mathrm{H}_{2} \mathrm{O}\right)$ are purchased from Sinopharm Chemical Reagent Co., Ltd (Shanghai, China) in analytical purity. Nano- $\mathrm{CaCO}_{3}$ was purchased from Xintai Nano CO., China. Commercial electrocatalyst, 20 wt\% Pt on Vulcan XC-72 was purchased from Johnson Matthey Corp, which was denoted as JM20. $5 \%$ Nafion solution were purchased from DuPont.

\subsection{Fabrication of PCNFs}

The precursor nanofibers were prepared by a common electrospinning method. In a typical procedure, $0 \mathrm{~g}, 0.05 \mathrm{~g}, 0.1 \mathrm{~g}, 0.2 \mathrm{~g}$ and $0.3 \mathrm{~g}$ of nano- $\mathrm{CaCO}_{3}$ were dispersed in $9 \mathrm{~g}$ of DMAc by sonication for 30 minutes, respectively. And then $0.7 \mathrm{~g}$ of PAN and 0.3g PMMA were added, and the mixture was heated at $40^{\circ} \mathrm{C}$ for $4 \mathrm{~h}$ under stirring to form a homogeneous suspension. The milky suspension was loaded into a plastic syringe equipped with a 23 gauge needle made of stainless steel. The needle was connected to a high-voltage supply. A piece of grounded aluminum foil was placed $18 \mathrm{~cm}$ below the tip of the needle to collect 
the nanofibers. The voltage was set at $18 \mathrm{kV}$, and the solution feeding rate was $0.9 \mathrm{~mL} \cdot \mathrm{h}^{-1}$. The white nonwoven mat composed of composite nanofibers was collected on the aluminum foil collector. The composite nanofibers obtained by electrospinning were preoxidized in air at $280^{\circ} \mathrm{C}$ for $1 \mathrm{~h}$ and then carbonized at $1400^{\circ} \mathrm{C}$ for $2 \mathrm{~h}$ under nitrogen protection to obtain porous carbon nanofibers. The PCNFs we obtained were denoted as PCNFs, PCNFs $\left(\mathrm{CaCO}_{3} 0.5 \%\right)$, PCNFs $\left(\mathrm{CaCO}_{3} 1 \%\right)$, PCNFs $\left(\mathrm{CaCO}_{3} 2 \%\right)$ and PCNFs $\left(\mathrm{CaCO}_{3} 3 \%\right)$.

\subsection{Preparation of the Electrocatalysts}

The preparation method and electrochemical evaluation of the catalyst are both based on the report of the research group. [11] $40 \mathrm{mg}$ of PCNFs were put into a three-necked flask and mixed with $30 \mathrm{ml}$ of EG and $15 \mathrm{ml}$ deionized water under ultrasonic treatment for $1 \mathrm{~h}$. Then $2 \mathrm{ml}$ of $\mathrm{H}_{2} \mathrm{PtCl}_{6} \cdot 6 \mathrm{H}_{2} \mathrm{O}$ was added into the slurry slowly to ensure about $20 \mathrm{wt} \% \mathrm{Pt}$ content, and continue to ultrasound for 1 h. After completion of the sonication, the mixture was stirred for $1 \mathrm{~h}$ and then heated to $140^{\circ} \mathrm{C}$ for $4 \mathrm{~h}$ under $\mathrm{N}_{2}$. After cooling down to room temperature, the mixture was washed with deionized water and acetone for several times in centrifuge. And then dried at $80^{\circ} \mathrm{C}$ in vacuum oven for $12 \mathrm{~h}$.

\subsection{Electrochemical evaluation of Electrocatalysts}

Three-electrode system was used for electrochemical test at room temperature. In the preparation of working electrode, $4 \mathrm{mg}$ catalyst was dripped into $2 \mathrm{ml}$ of Nafion/methanol solution and ultrasonicated for $1 \mathrm{~h}$ to get a homogeneous catalyst ink. Then, $20 \mu \mathrm{l}$ ink was dripped onto a clean glass carbon working ring disk electrode (RDE: $0.2472 \mathrm{~cm}^{2}$ ) using a pipette, and dry the ink by infrared lamp to bake for about 30 seconds. The liquid electrolyte was $0.1 \mathrm{M} \mathrm{HClO}_{4}$ aqueous solvent, $\mathrm{Pt}$ foil was used as the counter electrode and saturated calomel electrode (SCE) was employed as the reference electrode. All potentials in this work are referred to the reversible hydrogen electrode (RHE). The liquid electrolyte was bubbled with $\mathrm{N}_{2}$ and $\mathrm{O}_{2}$ about 30 minutes for cyclic voltammetry (CV) and linear sweep voltammetry (LSV) test.

\section{Results and Discussion}

Figure 1 showed the morphological structure of PCNFs. It can be seen that the diameter of PCNFs was about $200 \mathrm{~nm}$, and PCNFs had mesoporous structure, which were present at both the surface and the cross section. Moreover, surface of PCNFs were defective and rough, which was benefit the distribution and deposition of Pt nanoparticles. Comparing PCNFs $\left(\mathrm{CaCO}_{3}\right)$ with PCNFs without $\mathrm{CaCO}_{3}$, the PMMA-forming pores mainly appeared on the surface of the fiber, showing a gully-like shape. While the $\mathrm{CaCO}_{3}$-forming pores mainly distributed inside the fiber and can be observed in the section. In addition, with the increase of $\mathrm{CaCO}_{3}$, the pores of the fiber cross-section were significantly increased, when the content reached $3 \%$, the cross-section showing blasting pores.

The porosity of the PCNFs samples were determined by the $\mathrm{N}_{2}$ adsorp- 


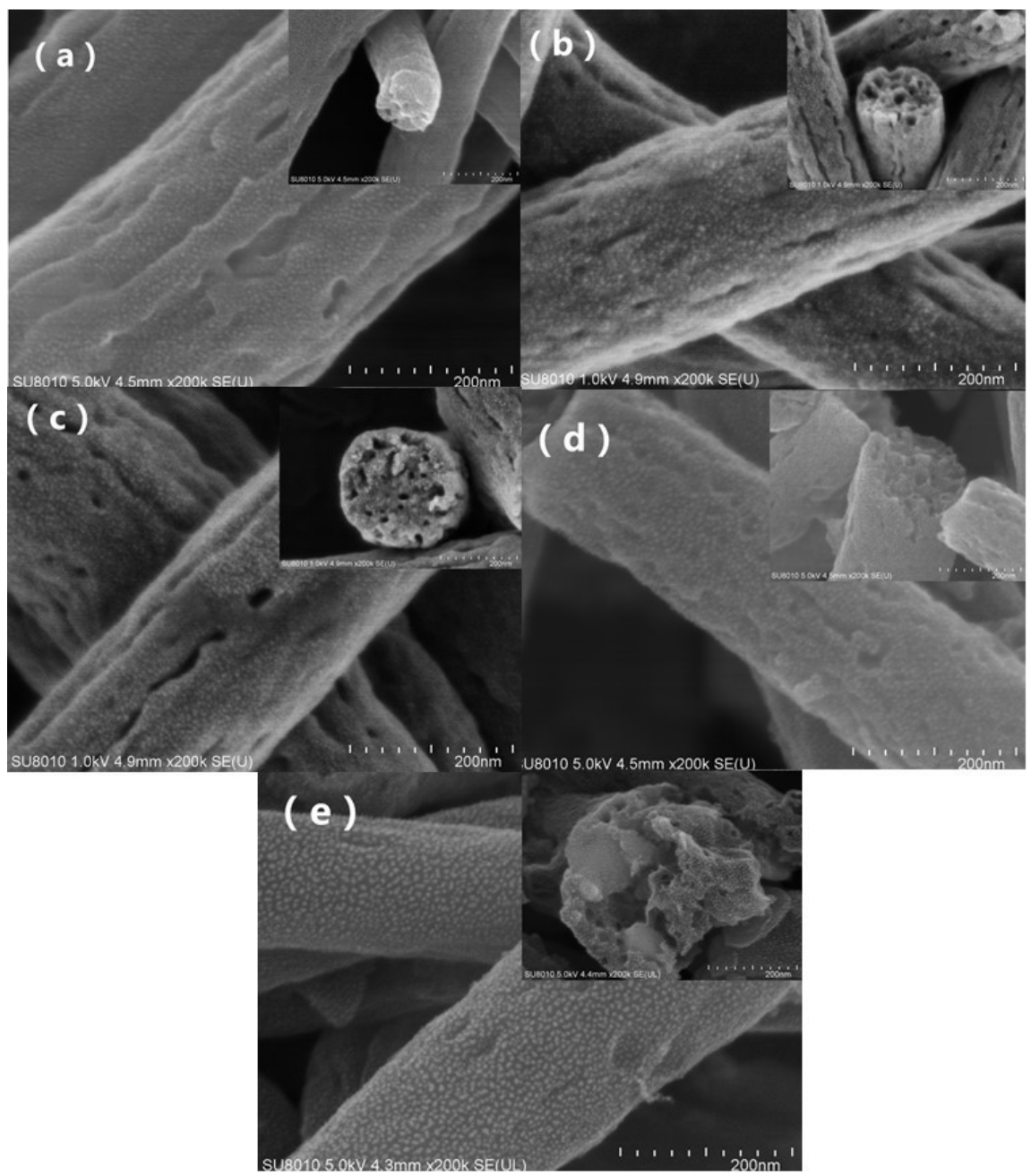

Figure 1. SEM images of PCNFs (a); $\mathrm{PCNFs}\left(\mathrm{CaCO}_{3}\right.$ 0.5\%) (b); $\mathrm{PCNFs}\left(\mathrm{CaCO}_{3} 1 \%\right)$ (c); $\mathrm{PCNFs}\left(\mathrm{CaCO}_{3} 2 \%\right)(\mathrm{d})$; and $\mathrm{PCNFs}\left(\mathrm{CaCO}_{3} 3 \%\right)(\mathrm{e})$.

tion/desorption method. Figure 2 showed the $\mathrm{N}_{2}$ adsorption/desorption isotherms of PCNFs, $\mathrm{PCNF}\left(\mathrm{CaCO}_{3} 0.5 \%\right)$, $\mathrm{PCNFs}\left(\mathrm{CaCO}_{3} 1 \%\right)$, $\mathrm{PCNFs}\left(\mathrm{CaCO}_{3}\right.$ $2 \%)$ and PCNFs $\left(\mathrm{CaCO}_{3} 3 \%\right)$. The BET surface areas were shown in Table 1. Pore-forming agents in the samples were PMMA and $\mathrm{CaCO}_{3}$. Mesoporous was formed by decomposing of PMMA at about $280^{\circ} \mathrm{C}$. $\mathrm{CaCO}_{3}$ was thermally decomposed into $\mathrm{CaO}$ and $\mathrm{CO}_{2}$ during carbonation, and the released $\mathrm{CO}_{2}$ would be an active ingredient, which contacted with the $\mathrm{C}$ elements in nanofibers and consumed it in the nanofibers according to the equation $\mathrm{CO}_{2}+\mathrm{C}=\mathrm{CO}$ and then formed mesoporous [12] [13]. The specific surface area gradually increased with the addition of $\mathrm{CaCO}_{3}$ content. However, when the $\mathrm{CaCO}_{3}$ content was too large, it would be agglomerated together to form macropores, therefore the specific surface area was reduced.

Figure 3 showed the TEM images of as-prepared PCNFs without $\mathrm{CaCO}_{3}$ (Fig. 3 (a)) and PCNFs $\left(\mathrm{CaCO}_{3}\right)$ (Figures 3(b)-(e)). The Pt nanoparticles simultaneously distributed in the surface, cross section and pore channels as shown in the figure. With the addition of $\mathrm{CaCO}_{3}$ content changes, the uniformity of the 


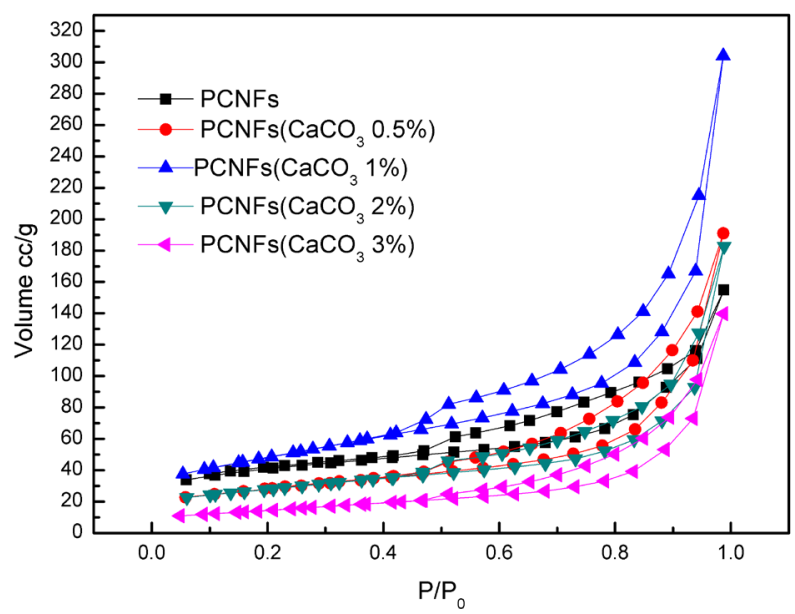

Figure 2. Nitrogen adsorption/desorption isotherms of PCNFs, PCNFs $\left(\mathrm{CaCO}_{3}\right.$ 0.5\%), PCNFs $\left(\mathrm{CaCO}_{3} 1 \%\right)$, PCNFs $\left(\mathrm{CaCO}_{3} 2 \%\right)$, PCNFs $\left(\mathrm{CaCO}_{3} 3 \%\right)$

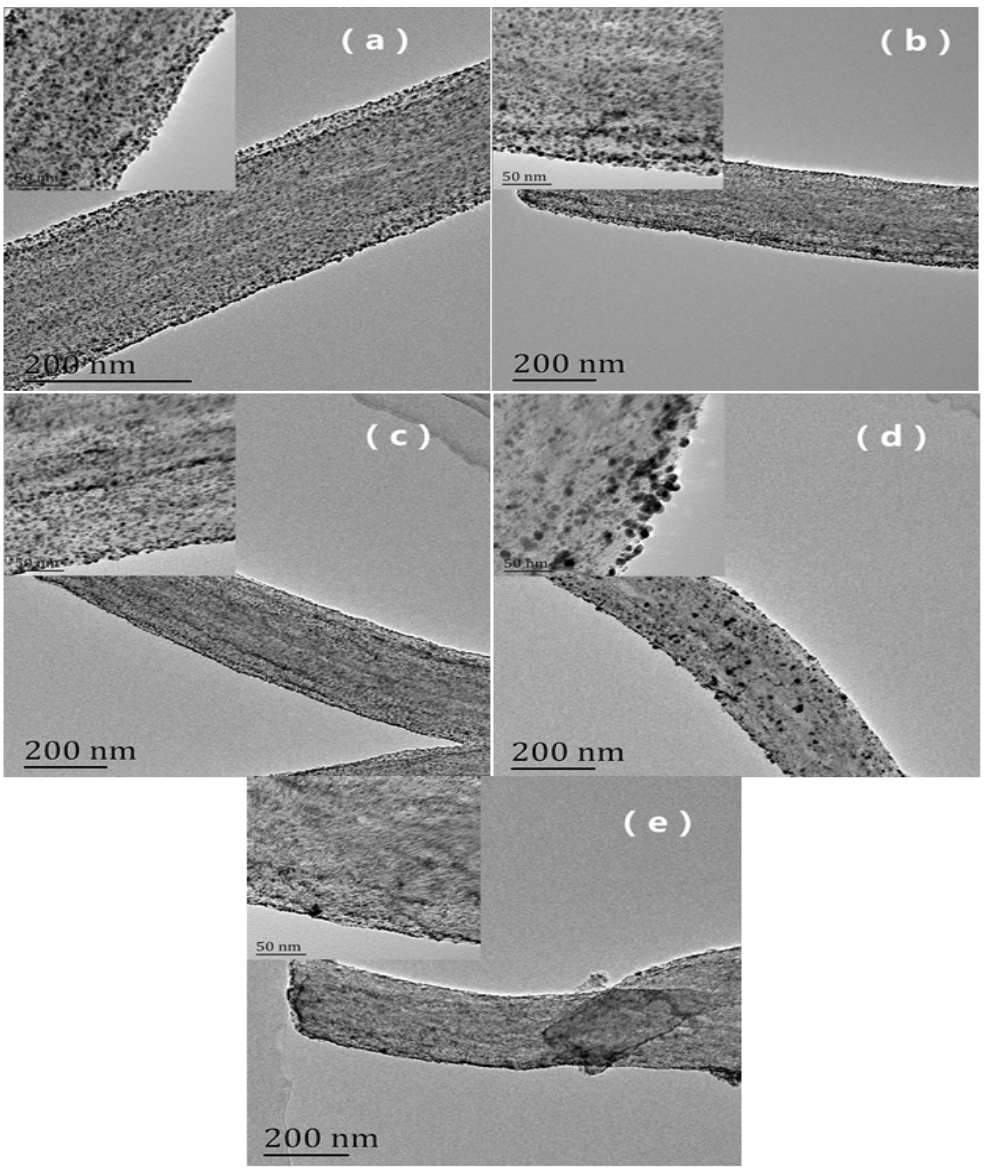

Figure 3. TEM images of PCNFs (a), $\mathrm{PCNFs}\left(\mathrm{CaCO}_{3}\right.$ 0.5\%) (b), $\mathrm{PCNFs}\left(\mathrm{CaCO}_{3} 1 \%\right)(\mathrm{c})$, $\mathrm{PCNFs}\left(\mathrm{CaCO}_{3} 2 \%\right)(\mathrm{d})$, and $\mathrm{PCNFs}\left(\mathrm{CaCO}_{3} 3 \%\right)(\mathrm{e})$

Table 1. BET surface area of PCNFs.

\begin{tabular}{cccccc}
\hline Sample & PCNFs & $\begin{array}{c}\mathrm{PCNF} \\
\left(\mathrm{CaCO}_{3} 0.5 \%\right)\end{array}$ & $\begin{array}{c}\mathrm{PCNF} \\
\left(\mathrm{CaCO}_{3} 1 \%\right)\end{array}$ & $\begin{array}{c}\mathrm{PCNF} \\
\left(\mathrm{CaCO}_{3} 2 \%\right)\end{array}$ & $\begin{array}{c}\mathrm{PCNFs} \\
\left(\mathrm{CaCO}_{3} 3 \%\right)\end{array}$ \\
\hline $\begin{array}{c}\text { Surfacearea } \\
\left(\mathrm{m}^{2} \cdot \mathrm{g}^{-1}\right)\end{array}$ & 135.037 & 152.468 & 169.699 & 96.671 & 52.045 \\
\hline
\end{tabular}


dispersion of Pt nanoparticles were different. The nanoparticles uniformity of PCNFs, PCNFs $\left(\mathrm{CaCO}_{3} 0.5 \%\right)$ and PCNFs $\left(\mathrm{CaCO}_{3} 1 \%\right)$ are relatively good compared with PCNFs $\left(\mathrm{CaCO}_{3} 2 \%\right)$ and $\mathrm{PCNFs}\left(\mathrm{CaCO}_{3} 3 \%\right)$. As can be clearly seen, partly aggregation of Pt particles occurs in PCNFs $\left(\mathrm{CaCO}_{3} 2 \%\right)$ and PCNFs $\left(\mathrm{CaCO}_{3} 3 \%\right)$, which resulted from a larger pore size on the fiber than that of $\mathrm{Pt}$ nanoparticles. Average size of Pt nanoparticles was approximately ranged from 2 to $4 \mathrm{~nm}$, when Pt showed smaller size distribution on $\mathrm{PCNFs}\left(\mathrm{CaCO}_{3} 1 \%\right)$ than that on PCNFs without $\mathrm{CaCO}_{3}$. The reason for the difference of dispersion of $\mathrm{Pt}$ nanoparticles in these samples may result from the change of size and quantity of mesoporous in the nanofibers.

Figure 4 showed the cyclic voltammograms (CVs) of the samples. As ob served, the CVs had obvious hydrogen adsorption/desorption peaks from $0 \sim 0.4$ $\mathrm{V}$ and Pt oxidation/reduction peaks from $0.6-0.9 \mathrm{~V}$. Obviously, the samples showed large area of hydrogen absorption. The electrochemical active surface (ECSA) which is an significant parameter used to represent the intrinsic activity of the Pt catalysts can be calculated based on the equation: $\mathrm{ECSA}=\mathrm{Q} /(0.21 \times$ $\mathrm{M})$, where $\mathrm{Q}(\mathrm{mC})$ is the electrical charge associated with monolayer adsorption of hydrogen on Pt with an assuming value of $210 \mu \mathrm{C} / \mathrm{cm}^{2}, \mathrm{M}$ is the Pt loading on the working electrode [14]. The results of ECSAs were about $77 \mathrm{~m}^{2} \cdot \mathrm{g}^{-1}$ and 82 $\mathrm{m}^{2} \cdot \mathrm{g}^{-1}$ for JM20 and Pt/PCNFs $\left(\mathrm{CaCO}_{3} 1 \%\right)$, respectively (Table 2$)$. ECSA values explained that the Pt/PCNFs $\left(\mathrm{CaCO}_{3} 1 \%\right)$ exhibited the highest electrocatalytic activity among these six catalysts. Besides the uniform dispersion of Pt nanoparticles, more mesoporous might provide the area for more Pt nanoparticles to load, and also supply extra and more active sites which could enhance electrochemistry activity.

The ORR activity of samples was obtained by rotating disk measurement $(\mathrm{RDE})$ at $1600 \mathrm{rpm}$ and was shown in Figure 5. As seen in the figure, the Pt/ PCNFs $\left(\mathrm{CaCO}_{3} 1 \%\right)$ exhibited the superior ORR activity compared with other

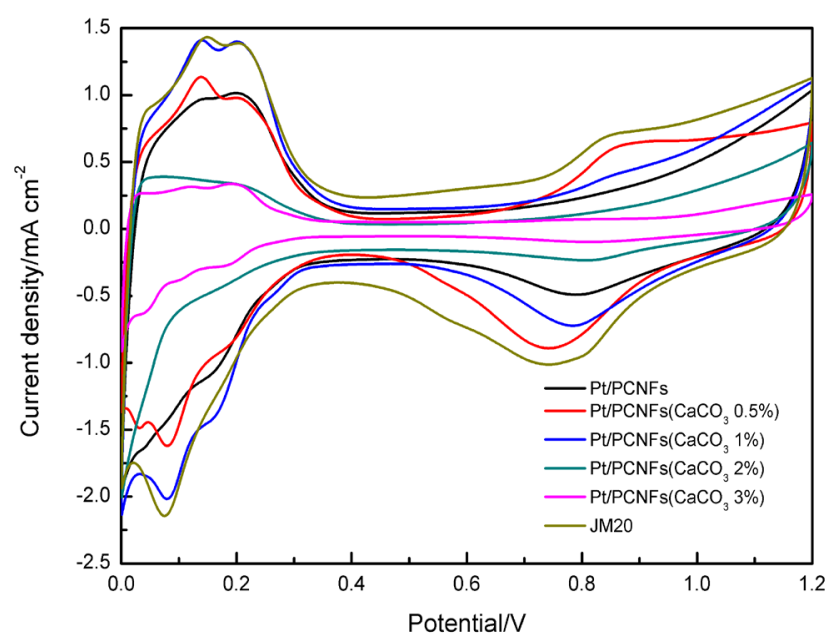

Figure 4. $\mathrm{CV}$ curves of $\mathrm{Pt} / \mathrm{PCNF}$, $\mathrm{Pt} / \mathrm{PCNF}\left(\mathrm{CaCO}_{3} 0.5 \%\right), \mathrm{Pt} / \mathrm{PCNF}\left(\mathrm{CaCO}_{3} 1 \%\right)$, $\mathrm{Pt} / \mathrm{PCNFs}\left(\mathrm{CaCO}_{3} 2 \%\right)$ and $\mathrm{Pt} / \mathrm{PCNF}\left(\mathrm{CaCO}_{3} 3 \%\right)$ in $0.1 \mathrm{M} \mathrm{HClO} 4$ at ambient solution temperature with a potential scanning rate of $50 \mathrm{mV} \cdot \mathrm{s}^{-1}$. 


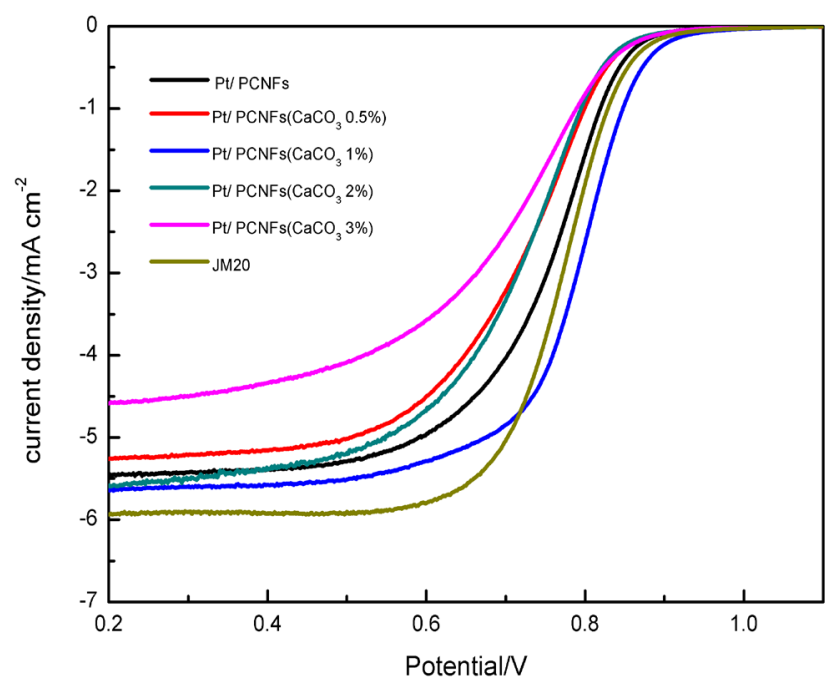

Figure 5. LSV curves of Pt/PCNFs, $\mathrm{Pt} / \mathrm{PCNFs}\left(\mathrm{CaCO}_{3} 0.5 \%\right), \mathrm{Pt} / \mathrm{PCNFs}\left(\mathrm{CaCO}_{3} 1 \%\right)$, $\mathrm{Pt} / \mathrm{PCNF}\left(\mathrm{CaCO}_{3} 2 \%\right)$ and $\mathrm{Pt} / \mathrm{PCNF}\left(\mathrm{CaCO}_{3} 3 \%\right)$ in $0.1 \mathrm{M} \mathrm{HClO}_{4}$ at ambient temperature with a potential scanning rate of $50 \mathrm{mV} \cdot \mathrm{s}^{-1}$ and $1600 \mathrm{rpm}$ electrode rotation speed.

Table 2. Totally results of the CV and LSV measurement.

\begin{tabular}{ccccc}
\hline Sample & $\mathrm{ECSA} / \mathrm{m}^{2} \cdot \mathrm{g}^{-1}$ & Onset potential/V & $\Delta \mathrm{E} 1 / 2 / \mathrm{V}$ & limited current \\
\hline $\mathrm{Pt} / \mathrm{PCNFs}$ & 60 & 0.90 & 0.762 & -5.446 \\
$\mathrm{Pt} / \mathrm{PCNFs}\left(\mathrm{CaCO}_{3}\right.$ 0.5\%) & 63 & 0.89 & 0.730 & -5.263 \\
$\mathrm{Pt} / \mathrm{PCNFs}\left(\mathrm{CaCO}_{3} 1 \%\right)$ & 82 & 0.93 & 0.799 & -5.633 \\
$\mathrm{Pt} / \mathrm{PCNFs}\left(\mathrm{CaCO}_{3} 2 \%\right)$ & 28 & 0.88 & 0.717 & -5.588 \\
$\mathrm{Pt} / \mathrm{PCNFs}\left(\mathrm{CaCO}_{3} 3 \%\right)$ & 23 & 0.89 & 0.715 & -4.587 \\
$\mathrm{JM} 20$ & 77 & 0.91 & 0.773 & -5.934 \\
\hline
\end{tabular}

catalysts. The onset potential of $\mathrm{Pt} / \mathrm{PCNFs}\left(\mathrm{CaCO}_{3} 1 \%\right)$ was $0.93 \mathrm{~V}, 30 \mathrm{mV}$ higher than Pt/PCNFs and even $20 \mathrm{mV}$ higher than commercial JM20. In addition, the half-wave potentials for Pt/PCNFs $\left(\mathrm{CaCO}_{3} 1 \%\right)$ were $0.799 \mathrm{~V}, 26 \mathrm{mV}$ higher than JM20 and $37 \mathrm{mV}$ higher than Pt/PCNFs, respectively. The results displayed that the increase of mesoporous greatly facilitated the catalytic activity.

\section{Conclusion}

In summary, PCNFs have been successfully prepared by using nano- $\mathrm{CaCO}_{3}$. PCNFs $\left(\mathrm{CaCO}_{3} 1 \%\right)$ had superior specific surface area compared with PCNFs without $\mathrm{CaCO}_{3}$, indicating that the introduction of $\mathrm{CaCO}_{3}$ could improve the structure of fibers and quantity of the mesoporous. Furthermore, PCNFs (Ca$\mathrm{CO}_{3} 1 \%$ ) also showed better electrocatalytic activity than PCNFs without $\mathrm{CaCO}_{3}$ and even JM20, demonstrating the improvement of the structure and the increase in number of mesoporous which can make the dispersion of Pt nanoparticles more uniform and the size of it more smaller, which is beneficial to improve the electrochemical performance of Pt/PCNFs. 


\section{References}

[1] Xin, Y., Liu, J.G., Zhou, Y., Liu, W., Gao, J., Xie, Y., Yin, Y. and Zou, Z. (2011) Preparation and Characterization of Pt Supported on Graphene with Enhanced Electrocatalytic Activity in Fuel Cell. Journal of Power Sources, 196, 1012-1018. https://doi.org/10.1016/j.jpowsour.2010.08.051

[2] Liu, H.S., Song, C.J., Zhang, L., Zhang, J.J., Wang, H.J. and Wilkinson, D.P. (2006) A Review of Anode Catalysis in the Direct Methanol Fuel Cell. Journal of Power Sources, 155, 95-110. https://doi.org/10.1016/j.jpowsour.2006.01.030

[3] Hulicova, D., Kodama, M. and Hattori, H. (2006) Electrochemical Performance of Nitrogen-Enriched Carbons in Aqueous and Non-Aqueous Supercapacitors. Chemistry of Materials, 18, 2318-2326. https://doi.org/10.1021/cm060146i

[4] Wei, D., Liu, Y., Wang, Y., Zhang, H., Huang, L. and Yu, G. (2009) Synthesis of N-Doped Graphene by Chemical Vapor Deposition and Its Electrical Properties, Nano Letters, 9, 1752-1758. https://doi.org/10.1021/nl803279t

[5] Zhou, C.W., Kong, J., Yenilmez, E. and Dai, H.J. (2000) Modulated Chemical Doping of Individual Carbon Nanotubes. Science, 290, 1552-1555. https://doi.org/10.1126/science.290.5496.1552

[6] Lv, R., Cui, T., Jun, M.S., Zhang, Q., Cao, A., Su, D.S., Zhang, Z., Yoon, S.H., Miyawaki, J., Mochida, I. and Kang, F. (2011) Open-Ended, N-Doped Carbon Nanotube-Graphene Hybrid Nanostructures as High-Performance Catalyst Support, Advanced Functional Materials, 21, 999-1006. https://doi.org/10.1002/adfm.201001602

[7] Zhang, L.S., Liang, X.Q., Song, W.G. and Wu, Z.Y. (2010) Identification of the Nitrogen Species on N-Doped Graphene Layers and Pt/NG Composite Catalyst for Direct Methanol Fuel Cell, Physical Chemistry Chemical Physics, 12, 12055-12059. https://doi.org/10.1039/c0cp00789g

[8] Jafri, R.I., Rajalakshmi, N. and Ramaprabhu, S. (2010) Nitrogen Doped Graphene Nanoplatelets as Catalyst Support for Oxygen Reduction Reaction in Proton Exchange Membrane Fuel Cell. Journal of Materials Chemistry, 20, 7114-7117. https://doi.org/10.1039/c0jm00467g

[9] Maldonado, S. and Stevenson, K.J. (2005) Influence of Nitrogen Doping on Oxygen Reduction Electro Catalysis at Carbon Nanofiber Electrodes. Journal of Physical Chemistry, 109, 4707-4716. https://doi.org/10.1021/jp044442z

[10] Álvarez, G., Alcaide, F., Cabot, P.L., Lázaro, M.J., Pastor, E. and Solla-Gullón, J. (2012) Electrochemical Performance of Low Temperature PEMFC with Surface Tailored Carbon Nanofibers as Catalyst Support. International Journal of Hydrogen Energy, 37, 393-404. https://doi.org/10.1016/j.ijhydene.2011.09.055

[11] Wang, Y., Jin, J., Yang, S.L., Li, G. and Qiao, J.L. (2015) Highly Active and Stable Platinum Catalyst Supported on Porous Carbon Nanofibers for Improved Performance of PEMFC. Electrochimica Acta, 177, 181-189. https://doi.org/10.1016/j.electacta.2015.01.134

[12] Zhao, C., Wang, W., Yu, Z., Zhang, H., Wang, A. and Yang, Y. (2010) Nano-CaCO 3 as Template for Preparation of Disordered Large Mesoporous Carbon with Hierarchical Porosities. J. Mater. Chem, 20, 976-980. https://doi.org/10.1039/B911913B

[13] Blackman, J.M., Patrick, J.W., Arenillas, A., Shi, W. and Snape, C.E. (2006) Activation of Carbon Nanofibers for Hydrogen Storage. Carbon, 44, 1376-1385. https://doi.org/10.1016/j.carbon.2005.11.015

[14] Wang, Y., Jin, J., Yang, S.L., Li, G. and Jiang, J.M. (2016) Nitrogen-Doped Porous 
Carbon Nanofiber Based Oxygen Reduction Reaction Electrocatalysts with High Activity and Durability. International Journal of Hydrogen Energy, 41, 1117411184. https://doi.org/10.1016/j.ijhydene.2016.04.235

Submit or recommend next manuscript to SCIRP and we will provide best service for you:

Accepting pre-submission inquiries through Email, Facebook, LinkedIn, Twitter, etc. A wide selection of journals (inclusive of 9 subjects, more than 200 journals)

Providing 24-hour high-quality service

User-friendly online submission system

Fair and swift peer-review system

Efficient typesetting and proofreading procedure

Display of the result of downloads and visits, as well as the number of cited articles Maximum dissemination of your research work

Submit your manuscript at: http://papersubmission.scirp.org/

Or contact msce@scirp.org 